\title{
Photoinduced decarboxylative azidation of cyclic amino acids
}

DOI:

10.1039/c8ob02702a

\section{Document Version}

Submitted manuscript

Link to publication record in Manchester Research Explorer

\section{Citation for published version (APA):}

Marcote, D. C., Street-Jeakings, R., Dauncey, E., Douglas, J. J., Ruffoni, A., \& Leonori, D. (2019). Photoinduced decarboxylative azidation of cyclic amino acids. Organic and Biomolecular Chemistry, 17(7), 1839-1842. https://doi.org/10.1039/c8ob02702a

\section{Published in:}

Organic and Biomolecular Chemistry

\section{Citing this paper}

Please note that where the full-text provided on Manchester Research Explorer is the Author Accepted Manuscript or Proof version this may differ from the final Published version. If citing, it is advised that you check and use the publisher's definitive version.

\section{General rights}

Copyright and moral rights for the publications made accessible in the Research Explorer are retained by the authors and/or other copyright owners and it is a condition of accessing publications that users recognise and abide by the legal requirements associated with these rights.

\section{Takedown policy}

If you believe that this document breaches copyright please refer to the University of Manchester's Takedown Procedures [http://man.ac.uk/04Y6Bo] or contact uml.scholarlycommunications@manchester.ac.uk providing relevant details, so we can investigate your claim.

\section{OPEN ACCESS}




\section{Journal Name}

\section{COMMUNICATION}

\section{Photoinduced Decarboxylative Azidation of Cyclic Aminoacids}

Received 00th January 20xx, Accepted 00th January 20xx

DOI: $10.1039 / x 0 \times x 00000 x$

\section{David C. Marcote ${ }^{a}$, Rosie Street-Jeakings ${ }^{a}$, Elizabeth Dauncey ${ }^{a}$, James J. Douglas ${ }^{b}$, Alessandro} Ruffoni* ${ }^{\mathrm{a}}$ and Daniele Leonori*a

www.rsc.org/

The direct decarboxylative azidation of cyclic $\alpha$-amino acids has been achieved via visible light-mediated organo-photoredox catalysis. This synthetic strategy allows the simple preparation of azide-contaning building blocks and has been used in the selective modification of $\mathbf{N}$-terminal proline residues of two di-peptides.

The azide is among the most important functional groups in organic chemistry, regularly used in research programs aimed at drug discovery, chemical biology and material science. ${ }^{1}$ This relevance stems from the ease by which organic azides can be converted into amines and amides (Staudinger reduction/ligation) as well as triazoles (click-chemistry dipolar cycloaddition) (Scheme $1 \mathrm{~A})$. $^{2}$

In general, alkyl azides are prepared by nucleophilic substitution of (pseudo)halides ${ }^{3 d}$, Mitsunobu reaction ${ }^{3 e}$ on alcohols, or alkene hydro-azidation ${ }^{3 a-c, g, f}$. More recently methods for direct $\mathrm{sp}^{3} \mathrm{C}-\mathrm{H}$ azidation ${ }^{4 \mathrm{a}-\mathrm{b}}$ have been developed using radical strategies based on $\mathrm{Mn}^{4 \mathrm{c}}$ and $\mathrm{Fe}^{4 \mathrm{~d}}$ systems. These approaches have enabled the modification of very complex substrates via the functionalization of the most activated $\mathrm{sp}^{3}$ $\mathrm{C}-\mathrm{H}$ bonds (i.e. the functionalization of tertiary centres over secondary). Radical approaches targeting the azidation of specific but non-activated $\mathrm{sp}^{3}$-carbons have generally relied in the preparation of Barton-type esters and their following decarboxylation-azidation using high-energy UV-light or AIBN at elevated temperature. ${ }^{5}$ More recently, $\mathrm{Li}^{6 \mathrm{a}}$ and $\mathrm{Jiao}^{6 \mathrm{~b}}$ have reported the direct oxidative conversion of carboxylic acids into alkyl azides using silver(I/II) catalysts and strong oxidants (e.g. $\mathrm{K}_{2} \mathrm{~S}_{2} \mathrm{O}_{8}$ ) in stoichiometric amounts.

As carboxylic acids represent a very versatile feedstock for the generation of alkyl radicals using photoredox catalysis, ${ }^{7}$ we were surprised to realise that no methodology has been

\footnotetext{
a. School of Chemistry, University of Manchester, Oxford Road, Manchester M13 9PL, UK. E-mails: alessandro.ruffoni@manchester.ac.uk and

daniele.leonori@manchester.ac.uk

b. Early Chemical Development, Pharmaceutical Sciences, IMED Biotech Unit, AstraZeneca, Macclesfield SK10 2NA, UK
}

Electronic Supplementary Information (ESI) available: Full experimental details and characterisation. See DOI: 10.1039/x0xx00000x developed for their engagement in $\mathrm{sp}^{3}-\mathrm{C}$ azidation. The realisation of this transformation would provide high complementarity to current methods both in terms of substrate scope and functional group compatibility given the mild conditions normally associated to visible-light photoredox catalysis. In this report, we describe the development of the first photoredox decarboxylative-azidation process. The methodology described here utilises low cost and readily available organic dyes as photocatalysts and it has been found particularly useful for the modification of cyclic aminoacids and di-peptides.

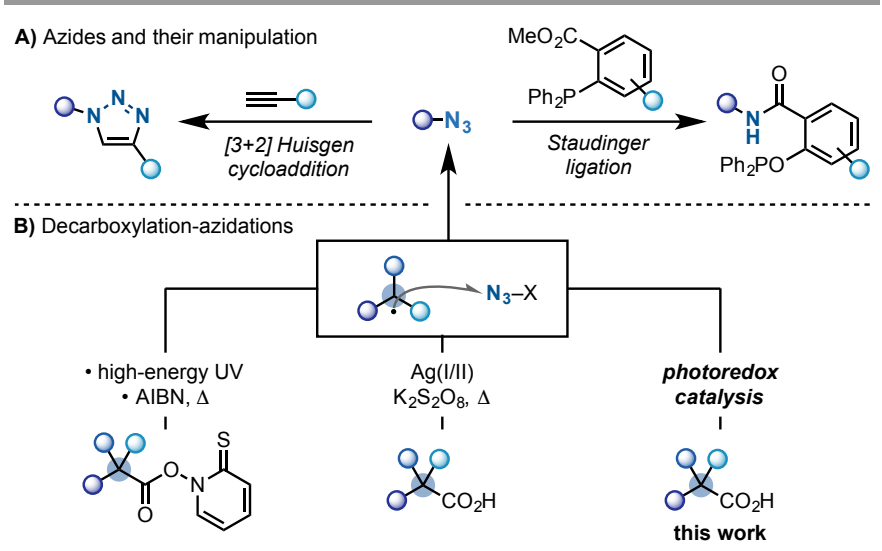

Scheme 1. A) Most used reactions of organic azides in bio-organic chemistry. B) Decarboxylative azidation procedures involving the generation of alkyl radicals.

Our proposed reaction manifold is based on a classical photoredox reductive quenching cycle where visible lightexcitation of a photocatalyst (PC $\rightarrow *$ PC) leads to the SET (single electron transfer) oxidation of a carboxylate starting material (A) (Scheme 2). ${ }^{8}$ Following a fast decarboxylation process, the resulting alkyl radical (B) can be intercepted by an $\mathrm{N}_{3}$-containing SOMOphile $\left(\mathrm{N}_{3}-\mathrm{Y}\right)$ to give the desired product $\mathbf{C}$. Examples of commercially available $\mathrm{N}_{3}$-SOMOphiles are the Zhdankin reagent ${ }^{9}$ (D) and aryl sulfonyl azides (E, F), which have been shown to efficiently transfer the azide group to alkyl radicals. ${ }^{10} \mathrm{~A}$ final SET between the radical generated upon 
azide-transfer $\left(\mathrm{Y}^{\circ}\right)$ and the reduced photocatalyst $\left(\mathbf{P C}^{\circ-}\right)$ would close the photoredox cycle ensuring catalytic activity.

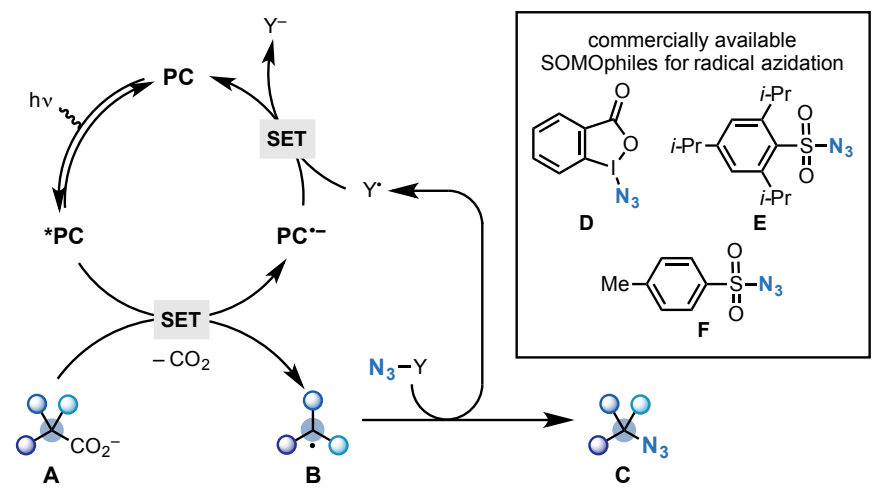

Scheme 2. Proposed photoredox cycle for decarboxylate azidation.

To assess our hypothesis, we started by investigating the reaction of SOMOphiles $\mathbf{D}-\mathbf{F}$ with $\mathbf{N}$-Boc-proline $\mathbf{1 a}$ as the carboxylic acid (1a-Cs $E^{\mathrm{ox}}=+0.95 \mathrm{~V}$ vs SCE in $\mathrm{CH}_{3} \mathrm{CN}$ ) and several photocatalysts. At the outset we decided to restrict our photocatalyst screening to organic dyes as they are considerably less expensive and commercially available on larger scale. ${ }^{11}$ As illustrated in Scheme 3, we were pleased to find out that using $\mathbf{E}$ as the SOMOphile, rhodamine $6 \mathrm{G}\left({ }^{*} E^{\text {red }}=\right.$ $+1.18 \mathrm{~V}$ vs $\mathrm{SCE}$ in $\mathrm{CH}_{3} \mathrm{CN}$ ) ${ }^{12}$ as the photocatalyst and $\mathrm{K}_{2} \mathrm{CO}_{3}$ as the base in DCE under green LEDs irradiation, $\mathbf{2}$ was obtained in a promising $36 \%$ yield (entry 1 ).

\begin{tabular}{|c|c|c|c|c|c|c|}
\hline \multirow[b]{2}{*}{ Entry } & \multirow{2}{*}{$\begin{array}{c}{ }_{\mathrm{N}} \lambda_{\mathrm{CO}_{2} \mathrm{H}} \\
1 \text { Boc } \\
1 \mathrm{a} \\
(1.0 \text { equiv. }) \\
\text { PC }\end{array}$} & \multirow{2}{*}{$\begin{array}{c}+\quad \mathrm{N}_{3}-\mathrm{Y} \\
\mathrm{D} / \mathrm{E} / \mathrm{F} \\
(2.0 \text { equiv. })\end{array}$} & \multicolumn{2}{|c|}{$\begin{array}{c}\mathrm{PC}(5 \mathrm{~mol} \%) \\
\text { base }(2.0 \text { equiv. }) \\
\begin{array}{c}\text { solvent, r.t., } 12 \mathrm{~h} \\
\text { visible light }\end{array}\end{array}$} & $\begin{array}{r}\text { Boc } \\
2\end{array}$ & \multirow[b]{2}{*}{ yield (\%) } \\
\hline & & & $N_{3}-Y$ & solvent & light & \\
\hline 1 & rhodamine $6 \mathrm{G}$ & $\mathrm{K}_{2} \mathrm{CO}_{3}$ & E & DCE & green LEDs & 36 \\
\hline 2 & rhodamine $6 \mathrm{G}$ & $\mathrm{NaHCO}_{3}$ & $\mathrm{E}$ & DCE & green LEDs & 51 \\
\hline 3 & rhodamine $6 \mathrm{G}$ & $\mathrm{CsHCO}_{3}$ & E & DCE & green LEDs & 55 \\
\hline 4 & rhodamine $6 \mathrm{G}$ & $\mathrm{CsOBz}$ & E & DCE & green LEDs & 90 \\
\hline 5 & rhodamine $6 \mathrm{G}$ & TMG & E & DCE & green LEDs & 85 \\
\hline 6 & rhodamine $6 \mathrm{G}$ & $\mathrm{CsOBz}$ & $\mathbf{F}$ & DCE & green LEDs & 50 \\
\hline 7 & rhodamine $6 \mathrm{G}$ & $\mathrm{CsOBz}$ & D & DCE & green LEDs & 15 \\
\hline 8 & rhodamine $6 \mathrm{G}$ & $\mathrm{CsOBz}$ & E & $\mathrm{CH}_{2} \mathrm{Cl}_{2}$ & green LEDs & 51 \\
\hline 9 & rhodamine $6 \mathrm{G}$ & $\mathrm{CsOBz}$ & E & $\mathrm{CH}_{3} \mathrm{CN}$ & green LEDs & 54 \\
\hline 10 & rhodamine $6 \mathrm{G}$ & $\mathrm{CsOBz}$ & E & THF & green LEDs & 72 \\
\hline 11 & rhodamine $6 \mathrm{G}$ & $\mathrm{CsOBz}$ & E & DMF & green LEDs & 30 \\
\hline 12 & methylene blue & $\mathrm{CsOBz}$ & E & DCE & blue LEDs & 32 \\
\hline 13 & riboflavine & $\mathrm{CsOBz}$ & $\mathrm{E}$ & $\mathrm{DCE}$ & blue LEDs & 39 \\
\hline 14 & mesityl acridinium & $\mathrm{CsOBz}$ & E & DCE & blue LEDs & 11 \\
\hline 15 & 4CzIPN & $\mathrm{CsOBz}$ & $\mathrm{E}$ & DCE & blue LEDs & 34 \\
\hline 16 & $\operatorname{eosin} Y$ & $\mathrm{CsOBz}$ & $\mathrm{E}$ & DCE & green LEDs & 15 \\
\hline 17 & - & $\mathrm{CsOBz}$ & E & DCE & green LEDs & - \\
\hline 18 & rhodamine $6 \mathrm{G}$ & - & E & DCE & green LEDs & _- \\
\hline 19 & rhodamine $6 \mathrm{G}$ & $\mathrm{CsOBz}$ & $\bar{E}$ & $\mathrm{DCE}$ & - & _- \\
\hline
\end{tabular}

Scheme 3. Optimization of the decarboxylative azidation using 1. B) Luminescence-quenching experiments.

We then screened several bases and found that by using the more soluble $\mathrm{CsOBz}$ and tetramethyl guanidine (TMG), the yield was improved to $90 \%$ and $85 \%$ respectively (entries $2-5$ ). Under these conditions the other azidating reagents $\mathbf{F}$ (entry 6 ) and $\mathbf{D}$ (entry 7) provided $\mathbf{2}$ in considerably lower yields. Other solvents (entries 8-11) and commonly used organophotocatalysts (entries 12-16) were evaluated but they generally provided $\mathbf{2}$ with lower efficiency.

Control experiments confirmed the requirement for light, photocatalyst and base (entries 17-19).

Our mechanistic proposal is further supported by luminescence-quenching studies (Stern-Volmer analysis) that revealed 1-Cs $\left(k_{\mathrm{q}}=2.110^{9} \mathrm{M}^{-1} \mathrm{~s}^{-1}\right)$ and not $\mathbf{E}$ to quench the excited state of rhodamine 6G (Scheme 4A). Unfortunately, quantum yield measurement has not been possible due to the lack of green-light actinometers. As a result, we cannot exclude the presence of radical chain propagations resulting, for example, by the direct oxidation of $A$ by $\mathbf{Y}^{*}$ (Scheme 4B).

A) Stern-Volmer analysis

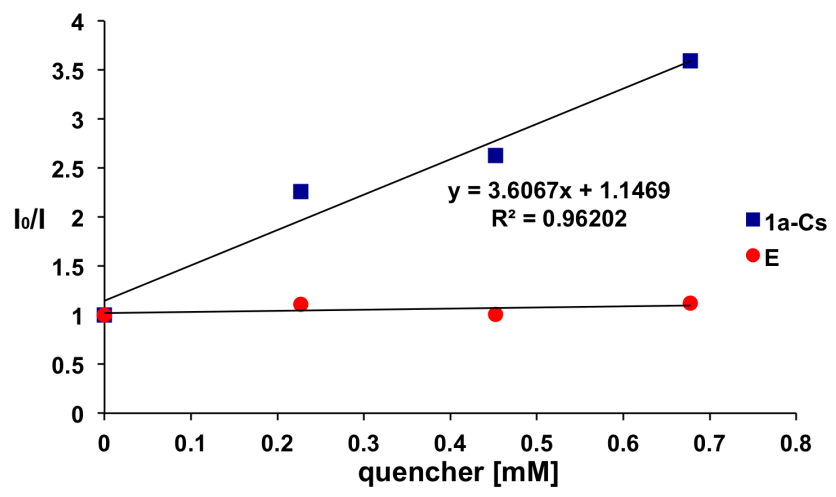

B) Possibility for radical chain propagation

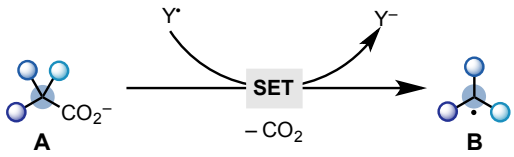

Scheme 4. Luminescence-quenching experiments.

With the optimised reaction conditions in hand, we evaluated the scope of the process (Scheme 5). Replacing the $N$-Boc protecting group with the $\mathrm{N}-\mathrm{Cbz}$ on proline was possible and we obtained $\mathbf{3}$ in good yield. Fluorinated pyrrolidines are common motifs in drugs for the treatment of diabetes (e.g. bisegliptin) $)^{13}$ and we successfully prepared C-2-azidated building block 4 in good yield but low dr. The octahydroindole2-carboxylic acid core is found in many ACE inhibitors like perindopril and was used (following $\mathrm{N}$-Boc protection) to access 5 in high yield. The chemistry could also be used to obtaine $\mathrm{C}-2$ azidated- $N$-Boc-indoline 6 . Six-membered-ring $N$ Boc-aminoacids were evaluated next and we successfully engaged pipecolic acid (giving 7 ) as well as substrates based on morpholine (8) and protected piperazine (9 and 10) heterocycles. Decarboxylative-azidation of tetrahydroisoquinoline carboxylic acids was possible and enabled the preparation of building blocks functionalised at C-1 (11) and C3 (12) positions. Saturated four-membered ring $N$-heterocycles 
are frequently used in medicinal chemistry programmes and we successfully applied the reaction to the C-2-azidation of $\mathrm{N}$ Boc-azetidine (13). ${ }^{14}$ Extension of this methodology to noncyclic aminoacids is a current limitation of the protocol and despite extensive re-optimization of the process we did not manage to achieve the decarboxylative-azidation of, for example, protected phenylalanine (14).

Secondary and primary carboxylic acids are sometimes difficult to engage in oxidative decarboxylative protocols and cannot be used as starting materials in this strategy. Tertiary substrates however are amenable as demonstrated by the formation of $\mathbf{1 7}$ and $\mathbf{1 8}$ which can be used to access derivatives of amantadine and memantidine, two blockbuster drugs for the treatment of the Parkinson and Alzheimer diseases respectively. In this case however, optimum yields were obtained using mesityl acridinium ${ }^{15}$ as the photocatalyst.

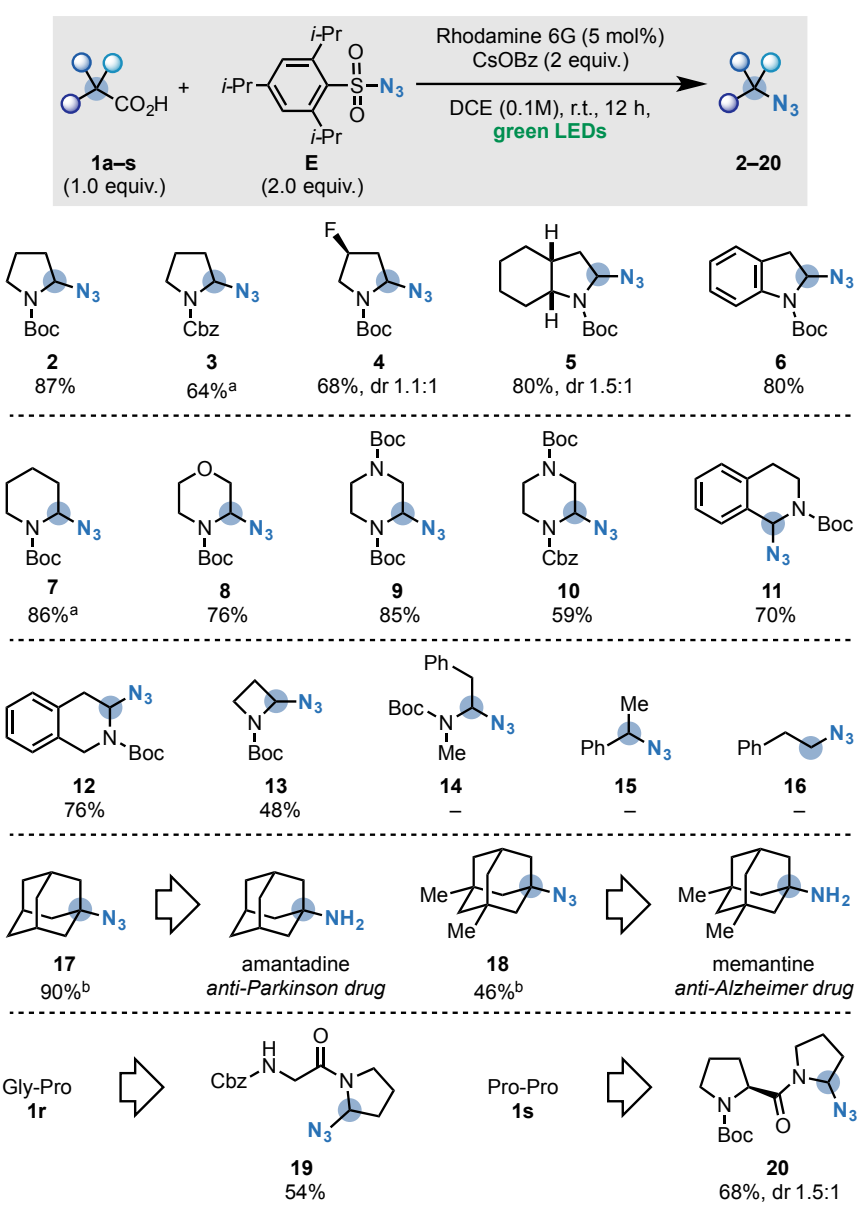

Scheme 5. Scope of the reaction. ${ }^{a}$ TMG was used as the base. ${ }^{b}$ MesAcrBF 4 was used as the photocatalyst.

To showcase the utility of this methodology we evaluated its applicability in the late-stage modification of terminal proline residues embedded in peptide structures. ${ }^{13}$ Pleasingly, commercially available Cbz-Gly-Pro-OH (1r) and Boc-Pro-Pro$\mathrm{OH}$ (1s) dipeptides were competent substrate and provided the azidated products 19 and 20 in good yields but low dr in the case of $\mathbf{2 0}$. To the best of our knowledge this is the first example of late-stage modification of peptides by decarboxylation-azidation.

\section{Conclusions}

In conclusion, we have developed the first visible-light mediated process that enables the preparation of organic azides by oxidative decarboxylation. The methodology has been successfully applied to the synthesis of several novel $\alpha$ $\mathrm{N}$-Boc-amino-azides building blocks and the late-stage functionalization of dipeptides.

D. L. thanks EPSRC for a research grant (EP/P004997/1). A. R. thanks the Marie Curie Actions for a Fellowship (703238). D. C. M. thanks the Xunta de Galicia for a Fellowship. E. D. thanks AstraZeneca for a PhD Case Award.

\section{Conflicts of interest}

There are no conflicts to declare.

\section{Notes and references}

1 (a) H. C. Kolb, M. G. Finn, K. B. Sharpless, Angew. Chem. Int. Ed., 2001, 40, 2004. (b) V. V. Rostovtsev, L. G. Green, V. V. Fokin, K. B. Sharpless Angew. Chem. Int. Ed., 2002, 41, 2596. (c) H. C. Kolb, K. B. Sharpless, Drug Discovery Today, 2003, 8, 1128. (d) S. Brase, C. Gil, K. Knepper, V. Zimmerman. Angew. Chem. Int. Ed., 2005, 44, 5188. (e) E. J. Moses, A. D. Moorhouse, Chem. Soc. Rev., 2007, 36, 1249. (f) S. Brase, K. Banert, Organic Azides: Syntheses and Applicatins, Eds. Wiley: 2009. (g) F. Amblard, J. H. Cho, R. F. Schinazi, Chem. Rev., 2009, 109, 4207. (h) R. K. Iha, K. L. Wooley, A. M. Nystrom, D. J. Burke, M. J. Kade, C. J. Hawker, Chem. Rev., 2009, 109,5620.

2 (a) H. Staudinger, J. Meyer, Helv. Chim. Acta, 1919, 2, 635. (b) R. Huisgen, Angew. Chem., 1963, 75, 604. (c) I. C. Schilling, N. Jung, M. Biskup, U. Scherpers, S. Brase, Chem. Soc. Rev., 2011, 40, 4840. (d) E. Lallan, R. Riguera, E. Fernandez-Magia, Angew. Chem. Int. Ed., 2011, 50, 8794. (e) P. Thirumurugan, D. Matosiuk, K. Jozwiak, Chem. Rev., 2013, 113, 4905.

3 (a) P. Panchaud, p. Renaud, Adv. Synth. Catal., 2004, 346, 925. (b) J. Waser, H. Nambu, E. M. Carreira, J. Am. Chem. Soc. 2005, 127, 8294. (c) J. Waser, B. Gaspar, H. Nambu, E. M. Carreira, J. Am. Chem. Soc., 2006, 128, 11693. (d) Y. Ju, D. Kumar, R. S. Varma, J. Org. Chem., 2006, 71, 6697. (e) J. E. Green, D. M. Bender, S. Jackson, M. J. O'Donnell, J. R. McCarthy, Org. Lett., 2009, 11, 807. (g) K. Weidner, A. Giroult, P. Panchaud, P. Renaud, J. Am. Chem. Soc. 2010, 132, 17511 (f) H. Chen, W. Yang, W. Wu, H. Jiang, Org. Biomol. Chem. 2014, 12, 3340.

4 (a) C. Viuf, M. Bols, Angew. Chem. Int. Ed., 2001, 40, 623. (b) Q. H. Deng, T. Bleith, H. Wadepohl, L. H. Gade, J. Am. Chem. Soc., 2013, 135, 5356. (c) H. Huang, T. M. Bergsten, J. T. Groves, J. Am. Chem. Soc., 2015, 137, 5300. (d) A. Sharma, J. F. Hartwig, Nature, 2015, 517, 600

5 (a) D. S. Masterson, N. A. Porter, Org. Lett. 2002, 4, 4253. (b) E. Nyfeler, P. Renaud, Org. Lett., 2008, 10, 985.

6 (a) C. Liu, X. Wang, Z. Li, L. Cui, C. Li, J. Am. Chem. Soc., 2015, 137, 9820, (b) Y. Zhu, X. Li, X. Wang, X. Huang, T. Shen, Y. 
Zhang, X. Sun, M. Zou, S. Song, N. Jiao, Org. Lett., 2015, 17, 4702

7 J. Xuan, Z. G. Zhang, W. J. Xiao, Angew. Chem. Int. Ed. 2015, 54, 15632

8 (a) C. K. Prier, D. A. Rankic, D. W. MacMillan, Chem. Rev. 2013, 113, 5322. (b) K. L. Skubi, T. R. Blum, T. P. Yoon, Chem. Rev., 2016, 116, 10035. (c) M. N. Hopkinson, B. Sahoo, J. -L. Li, F. Glorius, Chem. Eur. J., 2014 , 20, 3874.

9 V.V. Zhdankin, A. P. Krasutsky, C. J. Kuehl, A. J. Simonsen, J. K. Woodward, B. Mismash, J. T. Bolz, J. Am. Chem. Soc. 1996, 118, 5192.

10 K. Weidner, P. Renaud, Austr. J. Chem., 2013, 66, 341.

11 N. A. Romero, D. A. Nicewicz, Chem. Rev., 2016, 116, 10075

12 D. Magde, G. E. Rojas, P.G. Seybold, Photochem. and Photobiol. 1999, 70, 737.

13 D. Klaus, Boehringer Ingelheim Int, Patent : US8846695

14 D. C. Blakemore, L. Castro, I. Churcher, D. C. Rees, A. W. Thomas, D. M. Wilson, A. Wood, Nat. Chem., 2018, 10, 383

15 S. Fukuzumi, K. Ohkubo, Org. Biomol. Chem., 2014, 12, 6059.

16 S. J. McCarver, J. X. Qiao, J. Carpenter, R. M. Borzilleri, M. A. Poss, M. D. Eastgate, M. M. Miller, D. W. C. MacMillan, Angew. Chem. Int. Ed., 2017, 56, 728. (b) S. Bloom, C. Liu, D. K. Kölmel, J. X. Qiao, Y. Zhang, M. A. Poss, W. R. Ewing, D. W. C. MacMillan, Nat. Chem., 2017, 10, 205, 